\title{
Racial and Economic Diversity in U.S. Public Montessori Schools
}

\author{
Mira C. Debs \\ Yale University
}

\section{Acknowledgements}

Thanks to Jacqueline Cossentino, Sara Suchman, and Keith Whitescarver of the National Center for Montessori in the Public Sector; Katie Brown; Angela Murray; and the anonymous reviewers of the Journal of Montessori Research for their comments. Molly Landry Williams provided valuable assistance with source sleuthing. A portion of this analysis was conducted while serving as a Research Fellow for the National Center for Montessori in the Public Sector.

Keywords: diverse schools, public Montessori, low-income students, students of color, magnet, charter

Abstract. As public Montessori schools rapidly expand through the United States, the question then arises: What population of students do the schools serve? This study presents a new empirical data set examining the racial and economic diversity of 300 whole-school, public Montessori programs open in 2012-2013, where the entire school uses the Montessori Method. While schoolchoice scholars are concerned that choice programs like Montessori lead to greater student segregation by race and social class, this study finds a variety of outcomes for public Montessori. Public Montessori as a sector has strengths in student racial and socioeconomic diversity, but it also has diversity challenges, particularly among Montessori charters. The study concludes with recommended strategies for public Montessori schools to enroll a racially and economically diverse student body.

Public Montessori schools ${ }^{1}$, with 503 programs in 2015-2016, currently comprise approximately one eighth of an estimated 4,000 Montessori programs in the United States (American Montessori Society, 2016). As private Montessori schools expanded rapidly throughout the US in the 1960s (Meyer, 1975), public Montessori schools emerged a decade later as part of desegregation initiatives in cities around the country. The earliest whole-school public Montessori programs, in which the entire school follows the Montessori Method, were developed in the 1970s as part of desegregation initiatives in Cincinnati, OH; Kansas City, MO; and Milwaukee, WI. More recently, cities such as Cambridge, MA; Hartford, CT; Grand Rapids, MI; and Fort Wayne, IN, have implemented public Montessori education to create racial diversity in urban school districts (National Center for Montessori in the Public Sector [NCMPS], 2014a).

While a primary concern in the Montessori community has been the extent to which public Montessori programs maintain Montessori pedagogical fidelity (Daoust \& Suzuki, 2013, 2014; Kahn, 1990; Kostin, 1995; Lillard, 2012; McKenzie, 1994; Furman University, 2015a, 2015b; Van Acker, 2013), in the 
broader literature around public school choice ${ }^{1}$, scholars are concerned that choice options like public Montessori lead to racial segregation (Renzulli \& Evans, 2005; Orfield \& Frankenberg, 2012; Smrekar \& Goldring, 1999), where White and more-advantaged students are able to use school choice to exit traditional public schools. Recent news media reports ${ }^{2}$ have made similar charges, linking public Montessori to elite and White student enrollments in San Francisco, CA (Cobb \& Glass, 2009); Dallas, TX (Nicholson, 2016); and Charlotte, NC (Helms, 2015). A disproportionately White enrollment was grounds for blending a Montessori program at Leschi Elementary School in Seattle, WA (Nyland, 2015; Stocking, 2015). Montessori charters were denied in Santa Cruz, CA, and Salem, OR, on charges of elite enrollment (Brown, 2012; McCord, 2012; Schapiro, 2012; Wong, 2014), and several Montessori charter renewals, including the California Montessori Project in Elk Grove, CA ("EGUSD staff wants diversity," 2016), and in Chippewa Valley, WI (Swedien, 2014), are in jeopardy because of concerns their enrollments do not represent the diversity of the broader school districts.

Some initial research (Brown, 2016; Murray \& Peyton, 2008; Furman University, 2015c; Roberts \& Fleming 2016) has attempted to document the racial diversity in selected samples of public Montessori schools, but no research has measured the extent of this racial diversity across the entire public Montessori sector. At a time when public schools across the US are resegregating (Orfield, Kucsera, \& Siegel-Hawley, 2012), policymakers are more interested than ever in implementing school programs that act as engines of diversity. How successful are public Montessori programs in creating racial and socioeconomic diversity?

School-choice researchers also distinguish between the impact on diversity of different kinds of school choices (Frankenberg \& Siegel-Hawley, 2008; Frankenberg, Siegel-Hawley, \& Wang, 2010; Renzulli \& Evans, 2005). Magnet schools - choice schools that are part of existing school districts - are generally established as part of racial desegregation efforts in urban areas. They are typically required to meet a target enrollment of students from particular racial and ethnic backgrounds in order to respond to a desegregation court order. Charter schools - tuition-free schools chartered by the state but run by private organizations - can be created by any group looking for an education alternative. Charter schools have historically been held more accountable for their academic results than for the enrollment demographics. Whole-school, public Montessori schools are nearly evenly split between magnet and charter schools (NCMPS, 2014a; Debs, 2016c). Thus, this study's second research question is: How does the racial and economic diversity of charter Montessori differ from that of district and magnet Montessori schools? This study answers the research questions by analyzing a unique national data set of public Montessori schools, using information from multiple Montessori sources and the 2012-2013 Common Core of Data from the U.S. Department of Education's National Center for Education Statistics, (U.S. Department of Education, 2013).

\section{Literature Review}

\section{Benefits of Racially and Socioeconomically Diverse Public Schools}

Researchers have found academic and social gains for all students attending racially and economically diverse schools, including higher overall academic achievement (Bohrnstedt, Kitmitto, Ogut, Sherman, \& Chan, 2015), as well as specific gains in mathematics (Berends \& Penaloza, 2010; Newton, 2010) and literacy (Benson \& Borman, 2010). Students in racially diverse schools also build more expansive social networks (Braddock \& Gonzalez, 2010; Goldsmith, 2010; Wells, Holme, Revilla, \&

\footnotetext{
${ }^{1}$ I include district, magnet and charter schools as part of public school choice, excluding private schools and school vouchers. Although some researchers and policy makers debate whether charter schools are public schools, as they are run by private organizations receiving public funding, I follow Kahlenberg and Potter (2014) and Frankenberg, Siegel-Hawley, and Wang (2010) in considering them public schools.

${ }^{2}$ In the absence of academic research on this topic, I relied on news sources to identify public awareness of patterns in public Montessori student enrollment.
} 
Atanda, 2009; Wells, Fox, \& Cordova-Cobo, 2016). Others have argued that maintaining school diversity is a critical component of the American democratic system (Hochschild \& Scovronick, 2003).

But despite this evidence, American public schools have been resegregating over the last 25 years (Orfield et al., 2012). Factors in this resegregation include the rolling back of desegregation court orders (Clotfelter, 2004; Orfield \& Frankenberg, 2013), White families continuing to move away from school districts that have concentrated populations of students of color (Goyette, Farrie, \& Freely, 2012; Goyette, Iceland, \& Weininger, 2014), and the education policy arena focusing on student achievement instead of racial diversity.

The policy conversation is now shifting. In the last several years, an increasing number of policymakers at both the grassroots and national levels are examining how to make American schools more racially and economically diverse (Kahlenberg, 2001; Kahlenberg \& Potter, 2014; Potter, Quick, \& Davies, 2016), and the federal government has recently allocated new grants for districts and schools promoting school diversity (U.S. Department of Education, 2016b).

\section{School Choice and School Diversity}

School choice - providing parents a series of educational options - has become the consensus tool for creating such diversity. The pupil assignment strategies and busing of the 1970s were politically unpopular. The residential segregation underlying most school assignments remains a persistent problem, particularly among White families with children (Goyette et al., 2014). Giving parents additional choices, and sometimes choices outside of their assigned school district, has emerged as the most palatable and expedient policy alternative (Frankenberg \& Siegel-Hawley, 2008; Kahlenberg \& Potter 2014; Orfield \& Frankenberg, 2013).

Yet there are limitations to how much schools of choice can effectively create racial and socioeconomic diversity. School choice requires that parents have the time and knowledge to research school options, navigate complicated choice systems, and, in some cases, provide their own transportation to school. Not surprisingly, research shows that low-income families and families of color are less likely to participate in school-choice programs (Pattillo, 2015; Pattillo, Delale-O'Connor, \& Butts, 2014; Pérez, 2011; Rhodes \& DeLuca, 2014). As a result, even programs designed to create racial diversity can end up unintentionally excluding low-income families and families of color. Nearly all public Montessori schools face the challenge of being choice schools, in that families must deliberately enroll rather than automatically be assigned to attend.

\section{Public Montessori and School Diversity}

While Montessori has long been popular in the private sector, it has also been a sought-after public school choice (Murray \& Peyton, 2008). Since the late 1960s, public Montessori has expanded exponentially through first magnet and then charter schools (NCMPS, 2014a). The literature on public Montessori has focused primarily on two issues: (a) examining how effectively public Montessori educators maintain high-fidelity Montessori implementation (Daoust \& Suzuki, 2013, 2014; Kahn, 1990; Kostin, 1995; Lillard, 2012; McKenzie, 1994; Furman University, 2015a, 2015b; Van Acker, 2013), and (b) evaluating public Montessori student outcomes (Ansari \& Winsler, 2014; Dohrmann, Nishida, Gartner, Lipsky, \& Grimm, 2007; Lillard \& Else-Quest, 2006). Few of these studies provide information about the racial or socioeconomic diversity of study participants, making it challenging to draw conclusions regarding the efficacy of public Montessori for specific subgroups of students.

As education researchers demonstrate the continued salience of race on student educational outcomes (Ferguson, 2000; Johnson, 2014; Lewis, 2003; Lewis \& Diamond, 2015; Lewis-McCoy, 2014), more recently, scholars are examining the academic, disciplinary, and social justice context of public Montessori's Black and Latino students (Ansari \& Winsler, 2014; Banks \& Maixner, 2016; Brown \& Steele, 
2015; Debs \& Brown, 2016; Stansbury, 2014; Yezbick, 2007). Such research suggests both opportunities and limitations with public Montessori in racially diverse contexts.

Much is still unknown about the student enrollment of the public Montessori sector as a whole and the demographic makeup of particular schools. The 1993 Montessori Public School Consortium [MPSC], the Public Montessorian 2005 directory (Schapiro, 2005), and the 2014 public Montessori census undertaken by the NCMPS (2014b) were important sources in documenting the number of public Montessori schools around the US over the last three decades. A few studies have examined the racial composition of groups of public Montessori schools. Murray and Peyton (2008) surveyed 85 public Montessori programs in 2008 and found that they were 59\% White. A study of South Carolina's 46 public Montessori programs found that their enrollment was slightly Whiter and more economically advantaged than the enrollment of both their surrounding districts and the average South Carolina public school (Roberts \& Fleming, 2016; Furman University, 2015c). No study has measured or evaluated the diversity of student enrollment in public Montessori schools across the United States.

\section{Methodology}

\section{Sample}

In order to measure student racial/ethnic and socioeconomic diversity in public Montessori schools nationwide, I created the American Public Montessori Historical (APMH) data set, an original data set of 724 public Montessori schools that were opened between 1912 and 2015. The APMH data set was derived from four primary data sources: (a) the 1987-2013 National Center for Educational Statistics (NCES) data on public schools, (b) the 2014 NCMPS All Montessori Census, (c) the 2005 Public Montessorian directory, and (d) the 1993 MPSC directory. The last three sources all relied on voluntary data submission from individual schools. In contrast, the NCES collects required data from all public schools and was a method of finding public Montessori schools omitted from other listings. The APMH data set does not include Head Start or publicly funded early childhood centers. To determine opening dates for schools, I relied on NCES data and numerous secondary archival and web resources for information about individual schools.

I did not attempt to evaluate the fidelity of the public Montessori programs, an important concern among Montessori educators, particularly in the public sector. If programs were reported as Montessori programs to NCMPS, the Public Montessorian, or MPSC, or if program titles in the NCES school database included the word "Montessori," I included them in the data set. Background research of each school via its website indicated that nearly all schools had one or more Montessori essential elements in their schools, including mixed-age classrooms, preschool programs, Montessori materials, and Montessori-trained teachers and classroom assistants (NCMPS, 2016), though the presence of these elements by no means indicated high-fidelity Montessori programming. Three schools, part of the Einstein Montessori Charter schools in Florida, had no explicit link to Montessori pedagogy. These schools were not included in the database and have now dropped Montessori from their names.

From the APMH data set, I created a subgroup of 470 public Montessori schools open in 20122013, the most recent year with comprehensive statistics on race, ethnicity, and student socioeconomic status. ${ }^{3}$ These 470 public Montessori programs were either whole-school programs or partial programs (a set of classrooms within a larger school). The NCES provides enrollment details only by entire school. Since media reports suggested patterns where some partial Montessori program enrollments were very different from the enrollment of the entire school (Nyland, 2015; Stocking, 2015), I dropped the 170 partialschool programs from my analysis, leaving a subset of 300 whole-school programs for which 2012-2013

\footnotetext{
${ }^{3}$ As of 2014, certain districts with high levels of student poverty switched from complete reporting of free and reduced lunch (FRL) data to using a Community Eligibility Provision. As Tegeler, Hilton, and McArdle (2014) explain, student FRL data going forward will no longer be a consistent measure for researchers to analyze schools nationwide.
} 
demographic data were available. ${ }^{4}$ These 300 whole-school public Montessori schools make up approximately two thirds of the 470 public Montessori programs open in 2013. Due to the size of the schoolwide programs, they make up a disproportionate student enrollment of 94,613 students, or $76 \%$, of approximately 125,000 public Montessori students around the United States (NCMPS, 2014a). ${ }^{5}$

Almost every public Montessori school is a school of choice, meaning that families must deliberately choose to enroll their children in public Montessori schools. Only a handful of public Montessori schools enroll nearly all students in a region, such as the Longview, TX, public school system, where the default pre-kindergarten and kindergarten programs are Montessori (Whitworth, 2016). Schoolchoice research suggested it was important to distinguish between Montessori charters and noncharters. Thus I coded these 300 whole-school public Montessori programs by type of school-choice program: charter, district, or magnet. Through research on school websites, I identified charter schools using the following indicators: (a) school name, (b) details of the school history, (c) autonomy from the local school district, or (d) presence of an independent board of directors. It was sometimes difficult to determine whether schools were magnet schools or part of another choice program in the district. Magnet schools are funded by federal and state governments through grants for desegregation initiatives, while other districtchoice programs have a variety of funding sources. In either case, these magnet or district-choice public Montessori schools function quite similarly: they are part of a larger public district and follow a districtwide enrollment strategy, like a lottery. For this reason, I combined the district and magnet schools into a single category.

Using the NCES Common Core of Data collected annually from schools, I compiled information on students' racial/ethnic background and eligibility for free and reduced lunch (FRL), a proxy measure for the concentration of low-income students in a school. (In 2012-2013, when these national data were collected, a family of four earning under $\$ 42,643$ was eligible for reduced-price lunch.) I also created a similar table for 2002-2003 public Montessori enrollment to evaluate the 10-year enrollment difference by race and socioeconomic background. In order to compare each public Montessori school's enrollment to that of the surrounding district, Katie Brown and I used NCES data to match each school with the district in which the school is located. Even though most charter schools are not officially part of a school district, we wanted to compare these charters to the district in which they were located.

\section{Analysis}

To answer the first research question about the total diversity of public Montessori schools as a sector, I calculated the number and percentage of two key categories for each school and district: (a) students of color and (b) FRL-eligible students. Students of color include non-White students who are Black, Latino, Asian, Native American, Pacific Islander, or multiracial. ${ }^{6}$ Researchers use a broad range of definitions to talk about school segregation and school diversity (Cotto \& Feder, 2014; Kahlenberg \& Potter, 2014; Orfield et al., 2012). This study follows NCES quartile breakdowns. I define schools with between $25 \%$ and $75 \%$ students of color as racially diverse, and schools with between $25 \%$ and $75 \%$ FRL-eligible students as socioeconomically diverse.

To answer the second research question, about FRL and student-of-color enrollment differences between charter Montessori and district/magnet Montessori schools, I made several calculations. I calculated the mean, standard deviation, and standard error for each group, charter, or district/magnet, using

\footnotetext{
${ }^{4}$ Roughly one quarter of the partial-school programs are located in South Carolina. Their demographics are analyzed in Roberts and Fleming (2016).

${ }^{5}$ This estimate of 125,000 students was derived by creating an estimate of the total number of students in partial Montessori programs. For each school, I used website research to determine the number of Montessori classrooms at each partial school and multiplied each classroom by an average estimate of 25 students.

${ }^{6}$ The term students of color is used instead of minority, with the recognition that Black, Latino, Asian, Native American, Pacific Islander, and multiracial students will soon form the majority of enrollment in U.S. public schools (U.S. Department of Education, 2016a).
} 
its concentration of students of color and FRL-eligible students. To evaluate whether there was a statistically significant difference between public Montessori schools and their surrounding districts, I used chi-squared tests, a statistical test to evaluate whether there is a substantial difference between two populations. Using the district percentages of students of color and of White students, I calculated an expected number of students of color and White students at each school, which I then compared to the actual value of students of color and White students at the school. For one degree of difference, chi-squared values of 3.841 and higher were statistically significant. Schools with a chi-squared value of less than 3.841 did not have a statistically significant difference in student enrollment compared to the surrounding district. I took the percentage of students of color at the school and then subtracted the total percentage of students of color in the district to derive a percentage difference. I identified the number of charter and district/magnet schools where students of color were underrepresented, not statistically different, or overrepresented. I followed the same procedure to calculate chi-squared values for the difference in number of FRL-eligible students between each public Montessori school and its surrounding district.

\section{Findings}

\section{Whole-School Montessori Sample in Context}

As a sample, these 300 whole-school public Montessori schools were located in 36 states and the District of Columbia. The states with the largest number of whole-school Montessori programs were Arizona (30 schools), California (24 schools), and Wisconsin ( 21 schools). ${ }^{7}$ Urban public Montessori schools made up $47 \%$ of the sample. There were 135 magnet/district schools (45\%) and 165 charter schools (55\%). In 2012-2013, the average school size was 315 students. $^{8}$

\section{Racial and Economic Diversity of the Public Montessori Sector}

In 2012-2013, whole-school public Montessori schools as a group enrolled a proportion of students of color similar to that of all U.S. public schools. Students of color-including Black, Latino, Asian and Pacific Islander, Native American, and multiracial students - made up 55\% of all public Montessori students, in comparison to $54 \%$ of all public school students. Figure 1 shows that much of the concentration of students of color came from the higher percentage of Black students $(27 \%)$ compared to the national average (15\%). Latino and Asian and Pacific Islander students were underrepresented in public Montessori compared to the national average.

Considering students by socioeconomic background, in 2012-2013 whole-school public Montessori schools enrolled a lower proportion of FRL-eligible students (40\%), in comparison to the national average (51\%). This difference meant that students at public Montessori schools were more economically advantaged than the total U.S. public student enrollment.

\footnotetext{
${ }^{7}$ NCMPS publications Growth of Public Montessori in the United States: 1975-2014 (2014a) and Census Report 2014 (2014b) include more detailed, descriptive statistics about the public Montessori sector as a whole, including the estimate that $31 \%$ of public Montessori schools serve adolescents.

${ }^{8}$ Readers may view the APMH data set here: https://goo.gl/mF7RHs and the 2012-2013 whole-school Montessori database here: https://goo.gl/uTQLdX.
} 


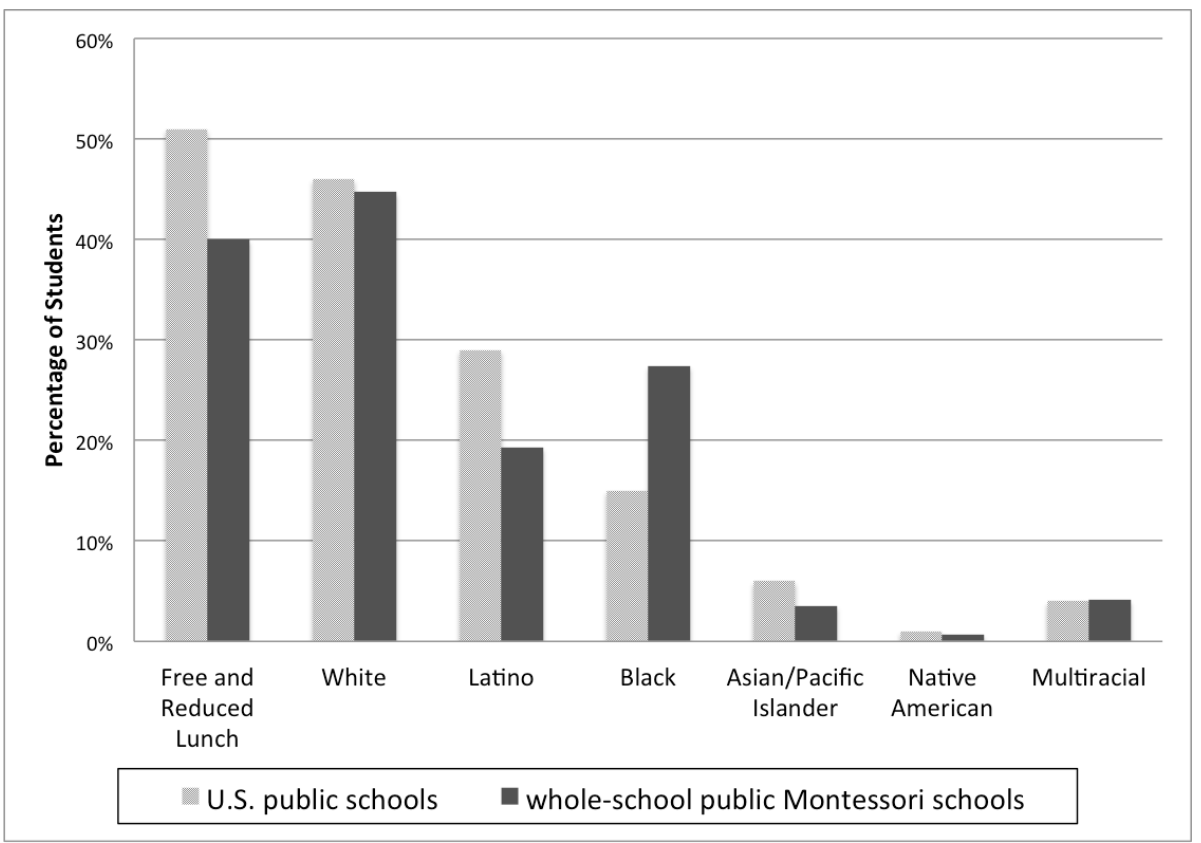

Figure 1. Percentage of students by racial/ethnic background and FRL status at 300 whole-school public Montessori schools compared to total U.S. public schools 2012-2013. Data from U.S. Department of Education (2013, 2015a, 2015b, 2016a).

To better illustrate the racial/ethnic diversity among the public Montessori student enrollment, Figure 2 shows that, while White students formed the largest share of whole-school public Montessori students (45\%), Black students made up $27 \%$ of the enrollment, Latino students 19\%, Asian and Pacific Islander 4\%, and Native American and Hawaiian students 1\%. In 2012-2013, the majority of public Montessori students in whole-school programs-52,313 students, or 55\% - were students of color, an important statistic given the perception that public Montessori disproportionately enrolls White students, and a considerable difference from earlier findings by Murray and Peyton (2008) and from the South Carolina state results (Furman, 2015c), both of which showed 59\% White student enrollments.

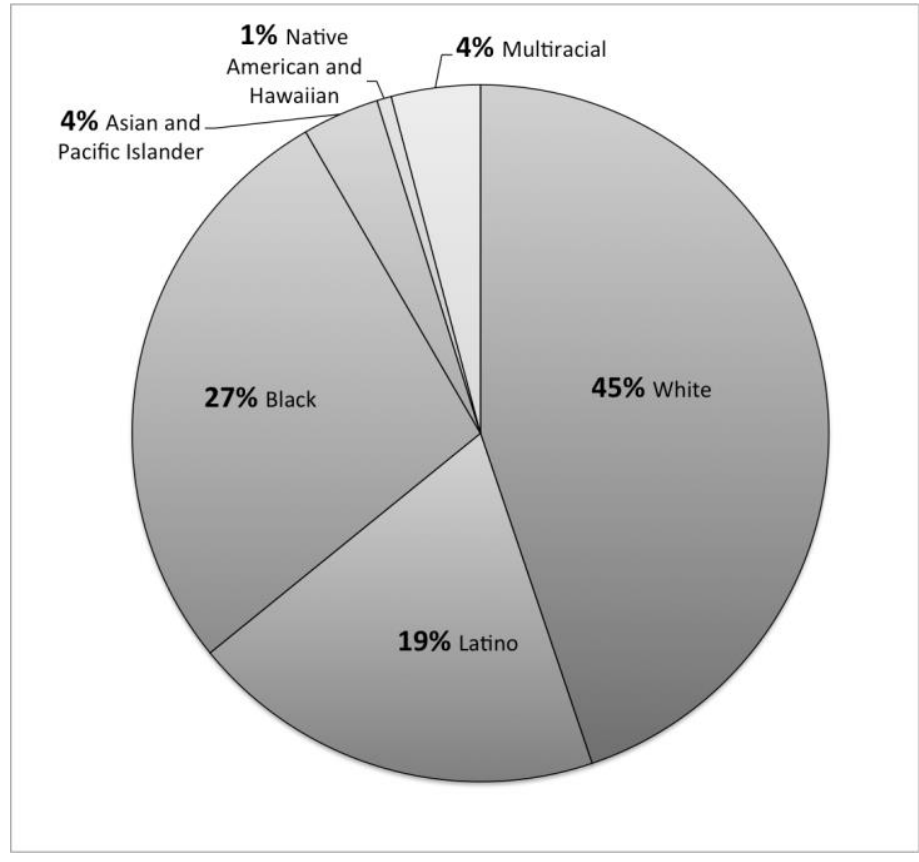

Figure 2. Enrollment percentage by race/ethnicity at whole-school public Montessori schools, 2012-2013. Data from U.S. Department of Education (2013).

Moreover, public Montessori schools had higher levels of racial/ethnic diversity in comparison to the total student enrollment in U.S. public schools. Figure 3 shows that in 2012-2013, 54\% of public Montessori 
students attended racially diverse schools, defined as schools where $25 \%-75 \%$ students of color were enrolled. This percentage is in comparison to only $40 \%$ of all U.S. students attending racially diverse public schools.

Public Montessori students also were less likely to attend schools with limited racial diversity. Nineteen percent of public Montessori students attended schools with $0 \%-25 \%$ students of color, compared to $32 \%$ of all U.S. public school students.
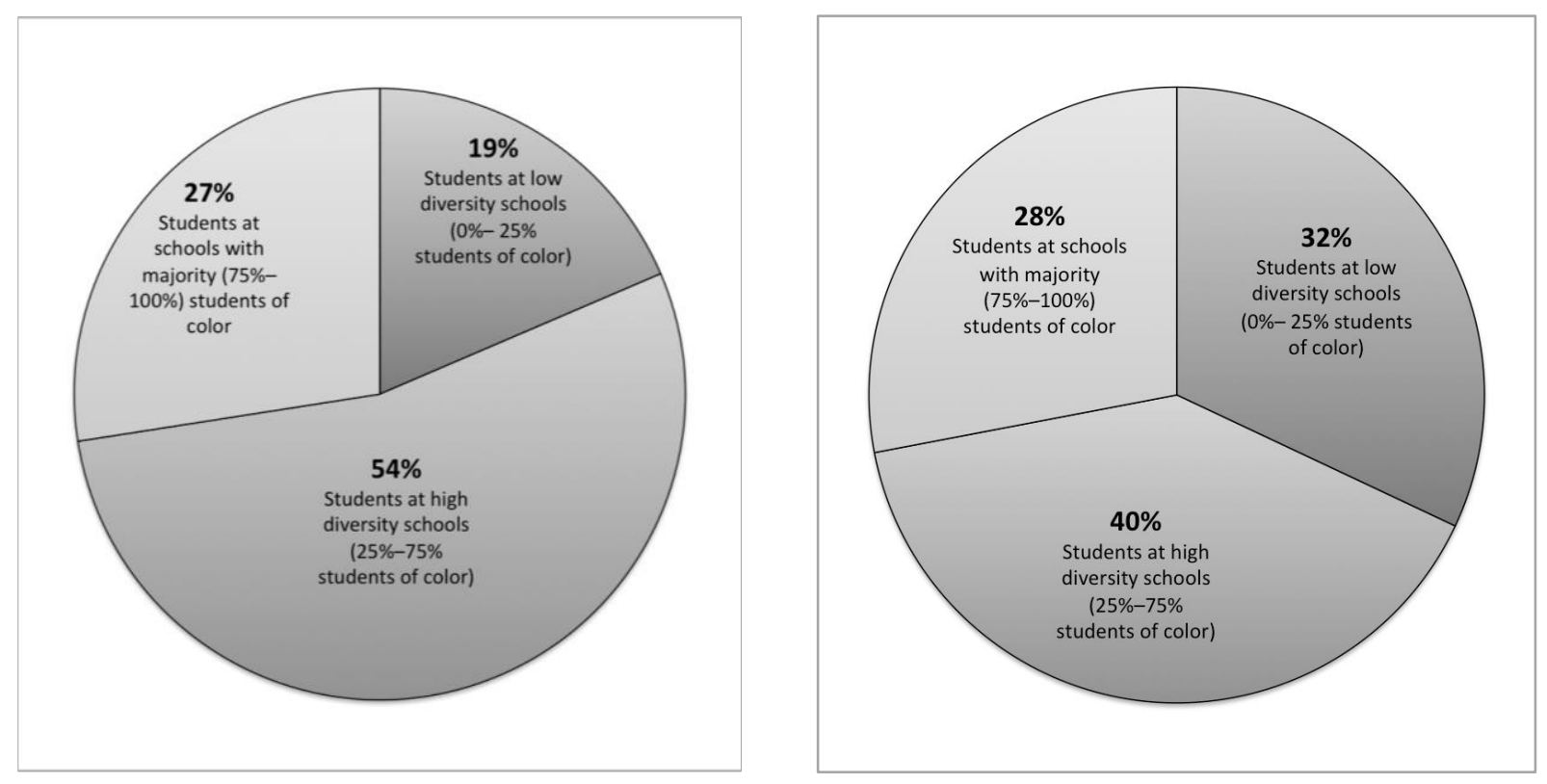

Figure 3. Distribution of public Montessori students and all U.S. public school students by percentage of students of color in the school. Data from U.S. Department of Education (2013, 2015b).

How does this student diversity impact public Montessori Latino and Black students, who have been shown to disproportionately attend racially isolated schools (Orfield et al., 2012)?

Figure 4 shows that both Black and Latino students attending public Montessori schools were more likely to attend racially diverse schools ( $25 \%-75 \%$ students of color) than their public school peers. Almost half of Latino public Montessori students attended racially diverse schools, compared to $34 \%$ nationally, which is particularly important to highlight given the trend that Latino student segregation is on the rise nationally (Orfield et al., 2012). Yet a substantial number — over half of Black Montessori students and 44\% of Latino Montessori students - still attended schools that were majority (75\%-100\%) students of color, though in both cases, this concentration was lower than the overall figures for Black and Latino students in U.S. public schools.

Thus, while public Montessori schools are more racially diverse overall than the national public school profile and serve a greater proportion of students of color, there is also evidence that some students of color are concentrated in racially isolated public Montessori schools. Although these students are receiving a Montessori education, they are not receiving the benefits of a racially diverse school. The next section examines how racial and socioeconomic differences vary between Montessori district/magnet schools and Montessori charter schools. 

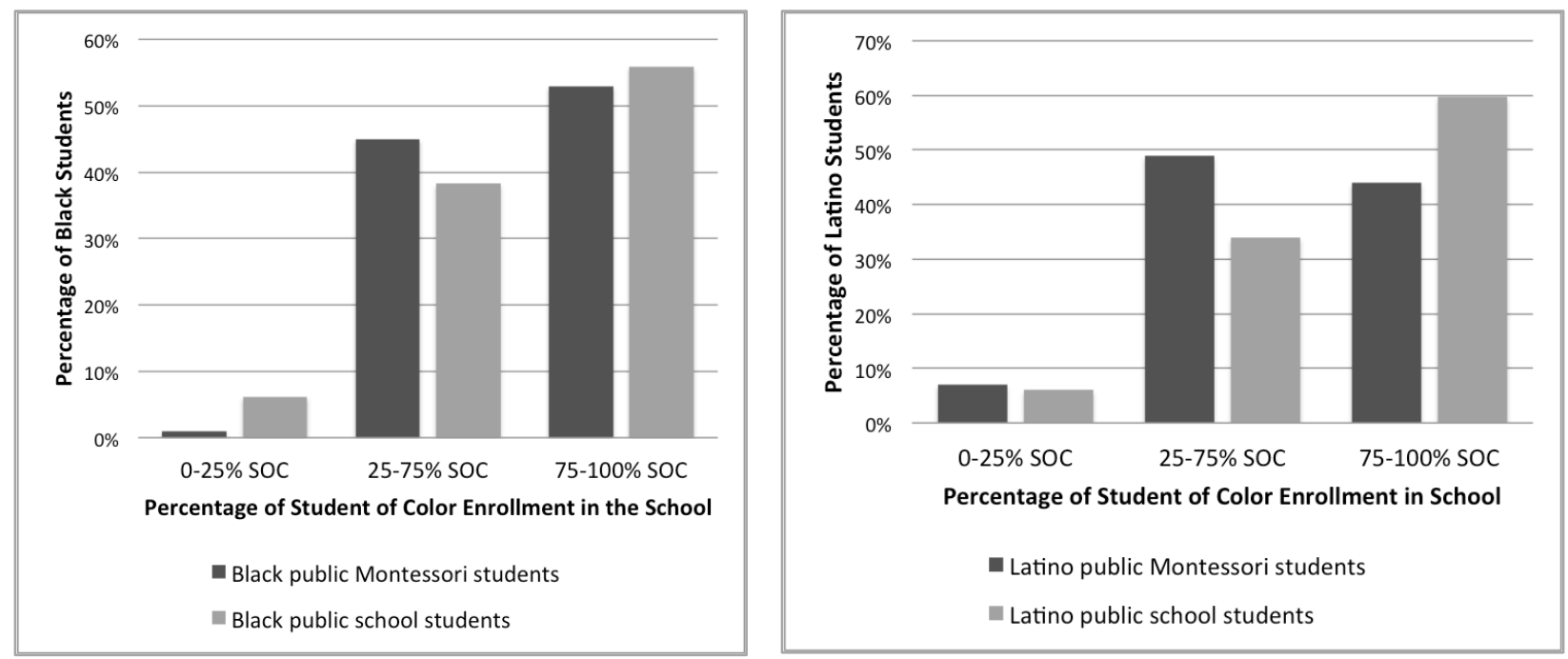

Figure 4. Distribution of Black and Latino students in public Montessori and all U.S. public schools by percentage of students of color in the school. Data from U.S. Department of Education (2013, 2015b).

\section{Racial and Economic Diversity in District/Magnet and Charter Montessori Schools}

Charter schools made up only 6\% of the nation's public schools in 2013 (U.S. Department of Education, 2015c). By 2015, in comparison, 41\% of public Montessori programs were charter schools (Debs, 2016b). As Figure 5 shows, in the 25 years since charter schools were first created in Minnesota, 238 charter Montessori schools have opened, only slightly fewer than the 314 new, district magnet schools. In the last 5 years, Montessori charter school growth has overtaken that of district/magnet schools as the public Montessori sector grows at a rapid pace.

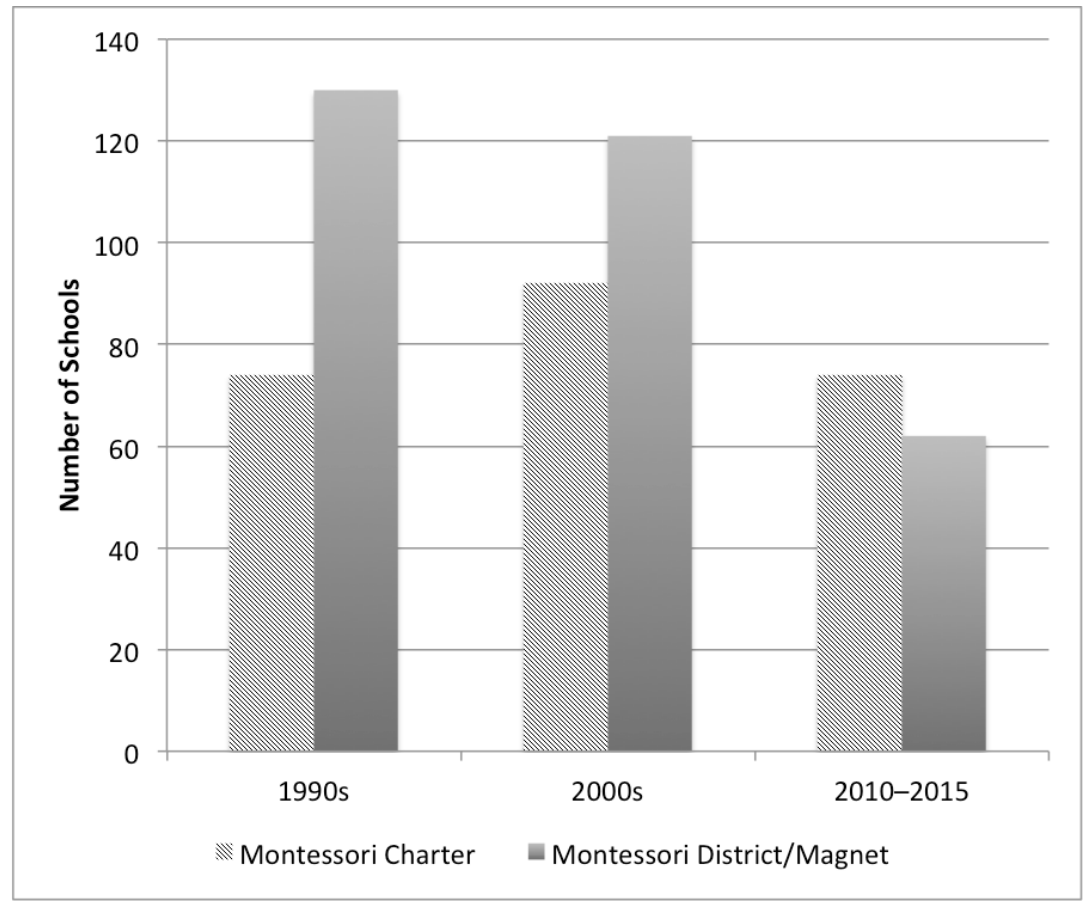

Figure 5. New district/magnet and charter Montessori schools, 19902015. Data from Debs, 2016 b. 
Although both magnet and charter schools are schools of choice that parents must voluntarily select, a critical difference between the two is that magnets were established as part of racial desegregation efforts. In contrast, charter schools have no accountability or incentives for racial diversity. While there certainly are racially diverse charters, Figure 6 shows the sizable difference between the mean (or average) percentage of students of color in Montessori charter schools and that of Montessori district/magnet schools. District/magnet Montessori schools enrolled a much higher percentage of students of color, with an average student-of-color enrollment of $61 \%$, compared with 39\% for charter Montessori schools.

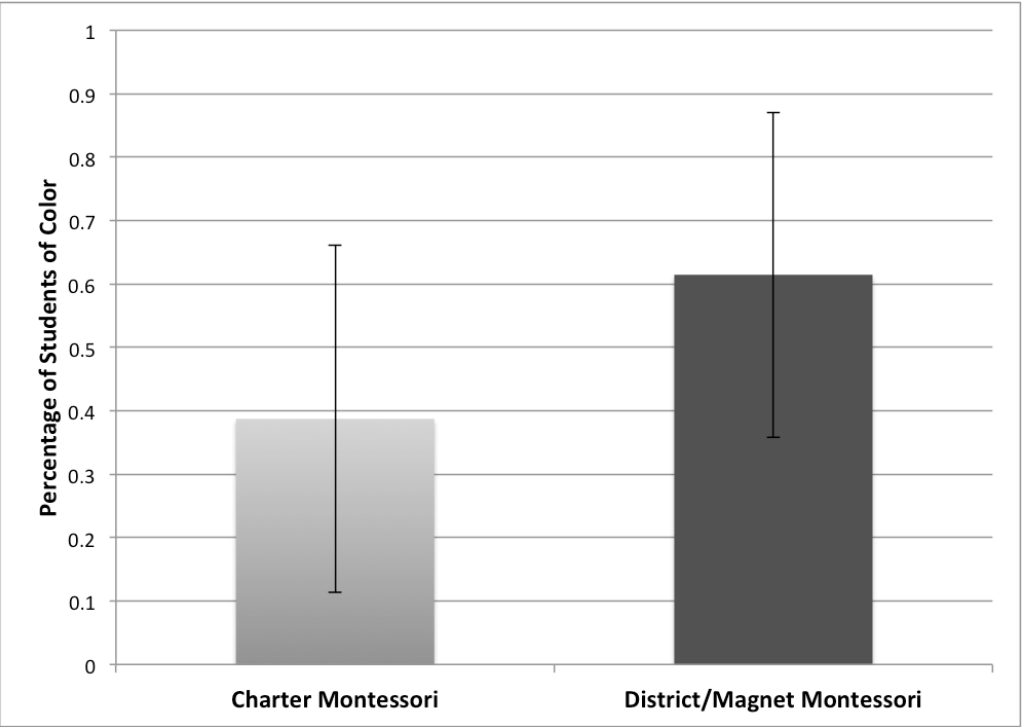

Figure 6. 2012-2013 mean percentage of students of color at whole-school charter schools compared to district/magnet Montessori schools, $+/-1$ $S D$. Data from Debs, 2016c. $S E$ (charter) $=.021 . S E($ district $/$ magnet $)$ $=.022$.

This lower level of charter diversity follows the pattern identified by Renzulli and Evans (2005), who demonstrated that many nonurban charters were driving White flight from traditional public schools.

Considering the level of socioeconomic diversity, Figure 7 shows a similar difference between charter Montessori schools and district/magnet Montessori schools. District/magnet schools averaged 50\% FRL-eligible students, and 1 standard deviation, or roughly two thirds, of district/magnet schools have between $25 \%$ and $75 \%$ FRL-student enrollment. Some have argued that this socioeconomic diversity is a critical component of successful learning for all students (Kahlenberg, 2001). In contrast, charter schools have an average of 31\% FRL-eligible enrollment. Twenty-three charter Montessori schools reported no FRL-eligible students.

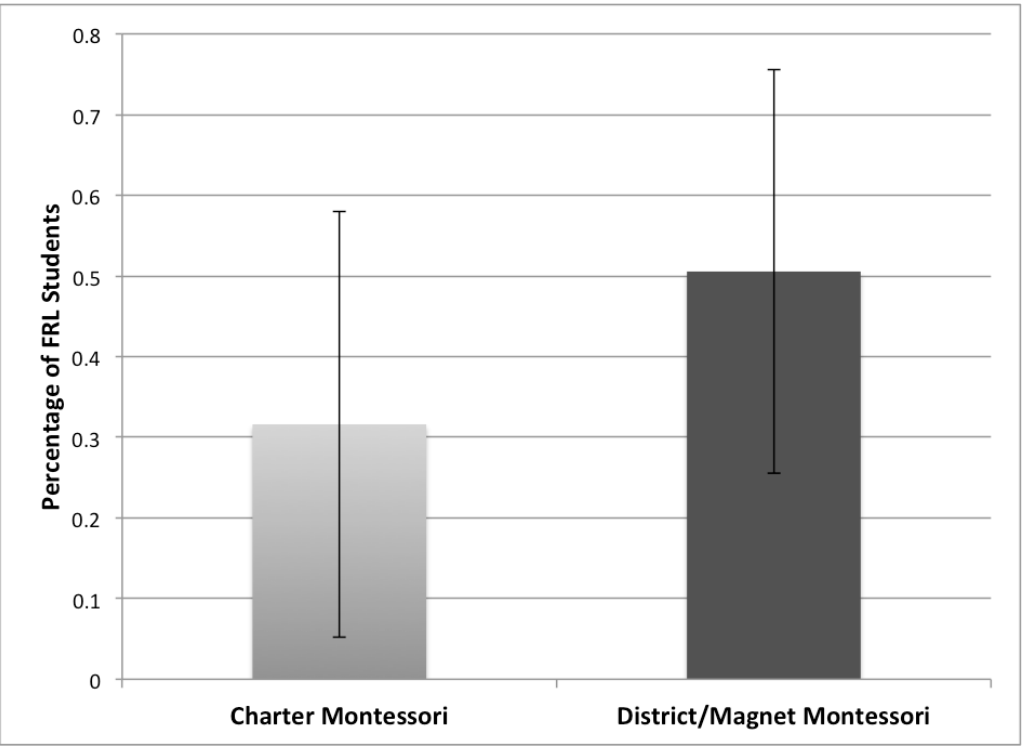

Figure 7. 2012-2013 mean percentage of free and reduced lunch-eligible (FRL) students at whole-school charter Montessori schools compared to district/magnet Montessori schools, +/-1 $S D$. Data from Debs, 2016c. $S E$ (charter $)=.020 . S E$ (district/magnet $)$ $=.022$. 


\section{Representativeness to District}

The desegregation mission of magnet schools offers one explanation for the difference in racial and economic diversity between district/magnet and charter Montessori schools. Another possibility is that, while magnet Montessori schools opened primarily in urban areas, many charter Montessori schools were created in small towns or rural areas whose small school districts would not have otherwise been able to support a magnet Montessori program. In these rural cases, low levels of student diversity might actually be representative of the broader district. Is this in fact the case? A chi-squared analysis (Table 1) showed no statistical difference in the percentage of students of color in surrounding districts in almost a quarter of both charter and district/magnet schools. However, two thirds of charters and half of all magnets enrolled a smaller proportion of students of color than did their surrounding districts.

Table 1

Montessori Charter and District/Magnet School Enrollments of Students of Color and Free and Reduced LunchEligible Students Compared to Surrounding School Districts

\begin{tabular}{|c|c|c|c|c|c|c|}
\hline $\begin{array}{l}\text { Difference in SOC enrollment } \\
\text { from district }\end{array}$ & \multicolumn{2}{|c|}{ Charters } & \multicolumn{2}{|c|}{ District / Magnet } & \multicolumn{2}{|c|}{$\begin{array}{c}\text { All public Montessori } \\
\text { schools } \\
\end{array}$} \\
\hline $\begin{array}{l}\text { Lower \% SOC enrollment than } \\
\text { district }\end{array}$ & 106 & $(64 \%)^{*}$ & 67 & $(50 \%)^{*}$ & 173 & $(58 \%)^{*}$ \\
\hline $\begin{array}{l}\text { No significant difference from } \\
\text { district }\end{array}$ & 37 & $(23 \%)$ & 31 & $(23 \%)$ & 68 & $(22 \%)$ \\
\hline $\begin{array}{l}\text { Greater \% SOC enrollment } \\
\text { than district }\end{array}$ & 22 & $(13 \%)^{*}$ & 37 & $(27 \%)^{*}$ & 59 & $(20 \%)^{*}$ \\
\hline Total & \multicolumn{2}{|c|}{165} & \multicolumn{2}{|c|}{135} & \multicolumn{2}{|c|}{300} \\
\hline \multicolumn{7}{|l|}{$\begin{array}{l}\text { Difference in FRL enrollment } \\
\text { from district }\end{array}$} \\
\hline $\begin{array}{l}\text { Lower \% FRL enrollment than } \\
\text { district }\end{array}$ & 116 & $(71 \%)^{*}$ & 83 & $(63 \%)$ & 199 & $(67 \%)^{*}$ \\
\hline $\begin{array}{l}\text { No significant difference from } \\
\text { district }\end{array}$ & 26 & $(16 \%)$ & 20 & $(15 \%)$ & 45 & $(16 \%)$ \\
\hline $\begin{array}{l}\text { Greater } \% \text { FRL enrollment } \\
\text { than district }\end{array}$ & 22 & $(13 \%)^{*}$ & 29 & $(22 \%)$ & 51 & $(17 \%)^{*}$ \\
\hline Total & \multicolumn{2}{|c|}{164} & \multicolumn{2}{|c|}{132} & \multicolumn{2}{|c|}{$296^{a}$} \\
\hline
\end{tabular}

The difference was even greater when examining students' socioeconomic backgrounds. At only $16 \%$ of charter schools and $15 \%$ of magnet schools were FRL-eligible enrollments comparable to those of their surrounding districts. In contrast, $71 \%$ of charters and $63 \%$ of magnets enrolled a smaller proportion of FRL-eligible students than did their surrounding districts. These results demonstrate that the majority of both charter and district/magnet Montessori schools, even those located in rural and suburban areas, enroll fewer students of color and FRL-eligible students than do their surrounding districts. ${ }^{9}$

A racially or socioeconomically diverse enrollment that is different from that of the surrounding district can be valuable when it helps reduce the racial and economic isolation of district students. It can be

\footnotetext{
${ }^{9}$ For a detailed analysis of Montessori charter enrollment by race compared to the surrounding district, see Brown (2016).
} 
problematic, however, when the public Montessori school enrolls a substantially more-advantaged population than does the surrounding district, and in certain instances leads to direct consequences for these schools. As mentioned in the introduction, news media have reported disproportionately White enrollments at public Montessori schools around the country, leading to program closures, denial of charter applications, and threatened charter renewals.

Longitudinal data over 10 years of public Montessori student enrollment show how the aggregate impact of charter growth may cause public Montessori schools to be less racially diverse in the future. Figure 8 shows that in the last 10 years, total White student enrollment has increased consistently, while Black student enrollment has remained the same.

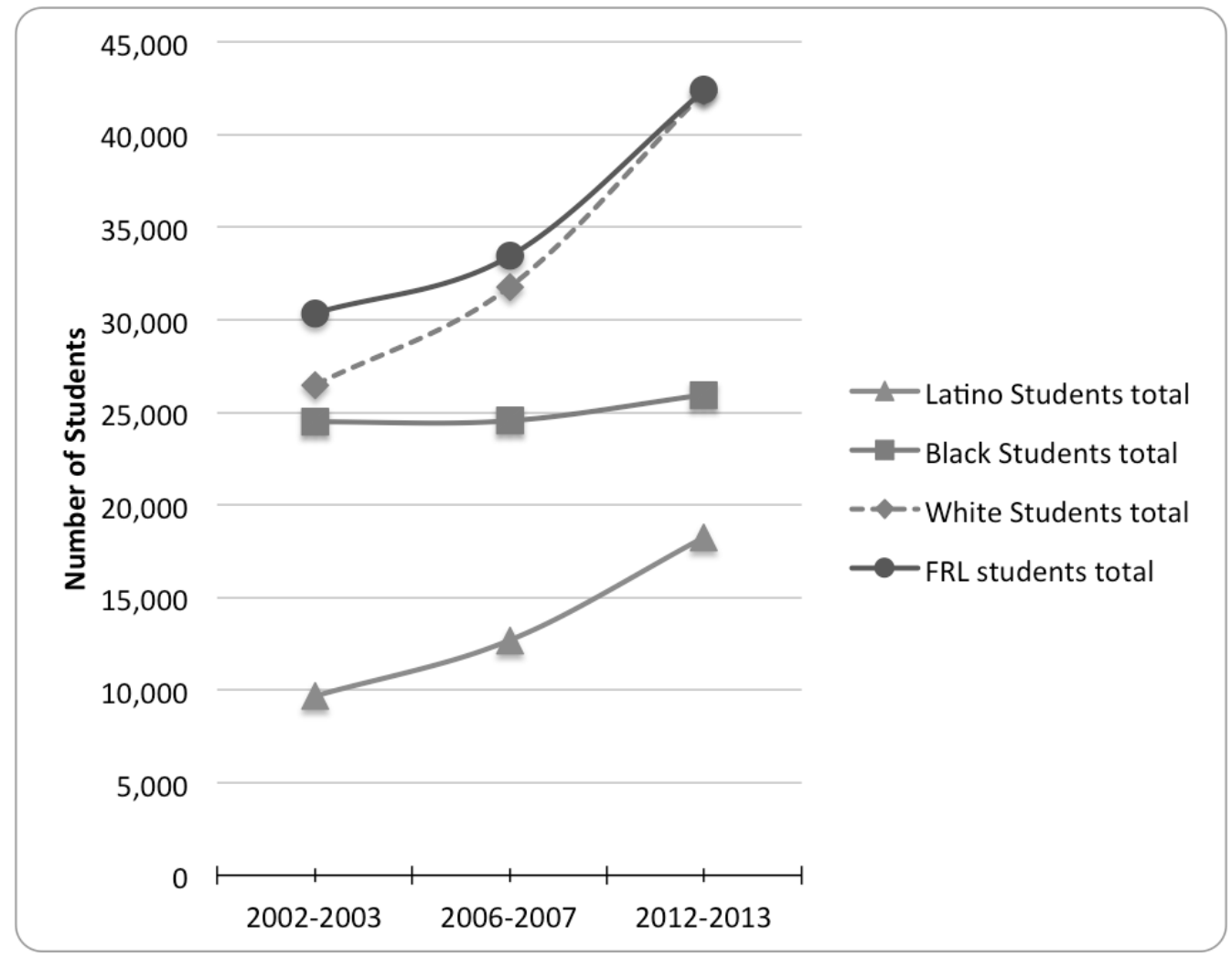

Figure 8. Ten-year change in wholeschool public Montessori student demographics, 20022012. FRL $=$ free and reduced lunch eligible. Data from U.S. Department of Education (2003, 2007, 2013).

Public Montessori is Whiter than it used to be. The historical data show this change may be due to the rise of Montessori charters and the closure of some urban magnets in majority-Black communities. At the same time, the number of FRL-eligible students and Latino students is growing at public Montessori schools nationwide. This increase may be due to the growth of charter Montessori programs in the West and Southwest, particularly in the charter-friendly states of Arizona, California, Colorado, and Texas.

Maintaining diversity is a challenge even for Montessori charters that began with explicit missions of racial diversity. Baltimore Montessori Public Charter School in Maryland and City Garden Montessori School in St. Louis, MO, have found their student populations to be increasingly White (Bowie, 2016; Prothero, 2016). Both schools now advocate measures to implement weighted charter lotteries in order to maintain a racially and economically diverse student body (Potter et al., 2016). In 2016, the Baltimore school board approved Baltimore Montessori's request to set aside 10\% of its seats for neighborhood residents, though this was a lower percentage than the school's initial request (Bowie, 2016). Thus for many public Montessori schools, enrolling a diverse population students is not only a social good, it is also a matter of remaining faithful to their original mission. 


\section{Discussion}

Like the broader school-choice sector, public Montessori schools have had both successes and limitations in creating racially and economically diverse schools. Data analysis of the racial and socioeconomic demographics of 300 whole-school public Montessori programs open in 2012-2013 indicates that these programs serve a majority of students of color, enroll a greater percentage of Black students in comparison to the national average, and continue to attract families from all racial, ethnic, and socioeconomic backgrounds. Students in a public Montessori school are more likely to attend a racially diverse school than are their national public school peers. Black and Latino public Montessori students are more likely to attend a racially diverse school than the U.S. cohort of Black and Latino public school students, who disproportionately attend racially isolated schools.

At the same time, not all public Montessori schools are racially and socioeconomically diverse. Half of Black and Latino students attend public Montessori schools with majority students of color. The percentage of FRL-eligible students at public Montessori schools is $11 \%$ lower than the national average. Charter Montessori schools are Whiter on average and enroll fewer low-income students than do district/magnet Montessori schools. In comparing charter Montessori schools to public schools in their surrounding districts, one third of them represented the demographics of their districts, while two thirds had a racially disproportionate enrollment, most commonly more White students (Brown, 2016). While in some cases, such disproportionality can help reduce racial and socioeconomic isolation, when the differences are stark, they can be grounds for terminating a Montessori program.

\section{Limitations}

This study has several limitations. In constructing a national data set of public Montessori schools, this study does not examine the fidelity of public Montessori programs beyond verifying that they have some link to the Montessori Method, though I recognize that Montessori fidelity remains an important concern to Montessori educators. Second, while this study demonstrates high levels of racial and socioeconomic diversity in public Montessori schools and areas where such diversity is limited, like Brown (2016), I cannot explain why certain schools are more or less representative of their districts. In some cases, this disparity may be due to limited recruitment efforts (Jabbar, 2016; Welner, 2013) and complicated enrollment processes, alongside an overwhelming number of White, middle-class applicants (Brown \& Makris, 2016). Montessori educators may also unintentionally deter some parents of color by downplaying academic outcomes in favor of focusing on the holistic and socioemotional benefits of the Montessori Method (Debs, 2016a).

In addition, now that a national data set of public Montessori schools has been established, additional research is needed to effectively evaluate the experience of students of color and low-income students in public Montessori programs. Policymakers, politicians, and district-level administrators frequently ask public Montessori educators whether the Method is effective for specific populations of students such as Blacks, Latinos, and English language learners. Though initial research has demonstrated both promising and mixed results for these student populations, research on Montessori is far from having an adequate answer to these questions. Examining test score data from a large sample of public Montessori schools disaggregated by student racial and socioeconomic cohort (similar to the school district-level research of Reardon and colleagues at the Stanford Center for Policy Analysis [Reardon, 2013, 2016]) would help us better understand to what extent racial and economic achievement gaps exist at public Montessori schools, as well as how these gaps compare to those in surrounding districts. Large-scale studies of lottery winners and losers who apply to enroll in public Montessori programs could help in examining the efficacy of Montessori over a number of years, particularly for low-income students and students of color. 


\section{Implications and Conclusion}

As a public school choice, public Montessori has the potential to lead the school-choice sector toward fulfilling its promise in creating racially and economically diverse schools. Public Montessori schools have been widely successful in bringing students from all racial and socioeconomic backgrounds together, but they must continue working to maintain this progress. In addition, public Montessori schools, and Montessori charter schools in particular, must be proactive in recruiting and sustaining their communities' most vulnerable families.

\section{AUTHOR INFORMATION}

Mira Debs is a post doctoral fellow in the Yale University Education Studies program and the Political Science department. She is a junior fellow of the Yale Center for Cultural Sociology and the Trinity College Cities, Suburbs and Schools Project. Her research focuses on public Montessori, school choice and diversity, and the formation of collective identity through schooling, art, and historical narratives.

\section{References}

American Montessori Society. (2016). Introduction to Montessori schools. Retrieved from http://amshq.org/Montessori-Education/Introduction-to-Montessori/Montessori-Schools

Ansari, A., \& Winsler, A. (2014). Montessori public school pre-K programs and the school readiness of low-income Black and Latino children. Journal of Education Psychology, 106(4), 1066-1079.

Banks, K., \& Maixner, R. A. (in press). Social justice education in an urban charter Montessori school. Journal of Montessori Research.

Benson, J., \& Borman, G. (2010). Family, neighborhood, and school settings across seasons: When do socioeconomic context and racial composition matter for the reading achievement growth of young children. Teachers College Record, 112(5), 1338-1390.

Berends, M., \& Penaloza, R. V. (2010). Increasing racial isolation and test score gaps in mathematics: A 30-year perspective. Teachers College Record, 112(4), 978-1007.

Bologna, J., Kantor, N., Liu, Y., \& Taylor, S. (2015). The right to stay put: City Garden Montessori School and neighborhood change. A Report for the Affordable Housing Task Force. Developing Sustainable Urban Communities, George Warren Brown School of Social Work, Sam Fox School of Design and Visual Arts, Washington University in St. Louis. Retrieved from https://csd.wustl.edu/Publications/Documents/city-garden_final-report.pdf

Bohrnstedt, G., Kitmitto, S., Ogut, B., Sherman, D., \& Chan, D. (2015). School composition and the BlackWhite achievement gap (NCES 2015-018). U.S. Department of Education, National Center for Education Statistics, National Assessment of Educational Progress. Retrieved from the National Center for Education Statistics.

http://nces.ed.gov/nationsreportcard/subject/studies/pdf/school_composition_and_the_bw_achiev ement_gap_2015.pdf

Bowie, L. (2016, February 22). City school board to decide if charter should welcome students who live nearby. Baltimore Sun. Retrieved from http://www.baltimoresun.com/news/maryland/bs-mdmontessori-vote-20160222-story.html

Braddock, J. H., II, \& Gonzalez, A. D. C. (2010). Social isolation and social cohesion: The effects of K-12 neighborhood and school segregation on intergroup orientations. Teachers College Record, 112(6), 1631-1653.

Brown, E., \& Makris, M. V. (2016, April). Too many white ping pong balls: The difficulty of diversity maintenance in prestige charter schools. Paper presented at the annual meeting of the American Educational Research Association, Washington DC.

Brown, J. M. (2012, February 22). Santa Cruz parents protest charter petition: Montessori school would start with 65 students in 2013. Mercury News. Retrieved from http://www.mercurynews.com/breaking-news/ci_20024457 
Brown, K. (2016, April). Racial diversity in Montessori charter schools. Paper presented at the annual meeting of the American Education Research Association, Washington DC. Available from http://www.aera.net/Publications/Online-Paper-Repository/AERA-Online-PaperRepository/Owner/952029

Brown, K. E., \& Steele, A. S. L. (2015). Racial discipline disproportionality in Montessori and traditional public schools: A comparative study using the relative rate index. Journal of Montessori Research, $1(1), 14-27$.

Clotfelter, C. T. (2004). After Brown: The rise and retreat of school desegregation. Princeton, NJ: Princeton University Press.

Cobb, C. D., \& Glass, G. V. (2009). School choice in a post-desegregation world. Peabody Journal of Education, 84(2), 262-278. doi: 10.1080/01619560902810187

Cotto, R., Jr., \& Feder, K. (2014). Choice watch: Diversity and access in Connecticut's school choice programs. Connecticut Voices for Children. Retrieved from http://www.ctvoices.org/sites/default/files/edu14choicewatchfull.pdf

Daoust, C., \& Suzuki, S. (2013, July). Montessori magnets and charters: Similarities and differences in implementation. Paper presented at the AMI International Congress, Portland, OR.

Daoust, C., \& Suzuki, S. (2014, March). Public Montessori elementary: Three models of implementation. Paper presented at the annual conference of the American Montessori Society, Dallas, TX. Retrieved from https://amshq.org/Publications-and-Research/ResearchLibrary/ /media/A46594F1338245308E679551118F7649.ashx.

Debs, M. (2016a, April). Conflicted fit: Black and Latino parents'experience in public Montessori schools. Paper presented at the annual meeting of the American Educational Research Association, Washington DC. Available from http://www.aera.net/Publications/Online-Paper-Repository/AERA-Online-PaperRepository/Owner/961581

Debs, M. (2016b). American Public Montessori Historical data set [Data file]. Retrieved from https://goo.gl/mF7RHs

Debs, M. (2016c). 2012-2013 whole-school Montessori data set [Data file]. Retrieved from https://goo.gl/uTQLdX

Debs, M., \& Brown, K. (2016). Students of color and public Montessori Schools: A review of the literature. Manuscript submitted for publication.

Dohrmann, K. R., Nishida, T. K., Gartner, A., Lipsky, D. K., \& Grimm, K. J. (2007). High school outcomes for students in a public Montessori program. Journal of Research in Childhood Education, 22(2), $205-217$.

EGUSD staff wants diversity in local charter schools. (2016, March 8). Elk Grove Citizen. Retrieved from http://www.egcitizen.com/articles/2016/03/08/news/doc56df70b6df8db588124584.txt

Ferguson, A. (2000). Bad boys: Public schools in the making of Black masculinity. Ann Arbor: University of Michigan Press.

Frankenberg, E., \& Siegel-Hawley, G. (2008). The forgotten choice? Rethinking magnet schools in a changing landscape. Civil Rights Project/Proyecto Derechos Civiles. Retrieved from http://escholarship.org/uc/item/5p42n2np

Frankenberg, E., Siegel-Hawley, G., \& Wang, J. (2010). Choice without equity: Charter school segregation and the need for civil rights standards. Civil Rights Project/Proyecto Derechos Civiles. Retrieved from http://escholarship.org/uc/item/4r07q8kg

Furman University, Riley Institute. (2015a). South Carolina public Montessori study: 2013-2014 implementation survey (selected summary). Retrieved from https://riley.furman.edu/sites/default/files/docs/MontImplSurveySummary13-14 \%2812 17 $14 \% 29 . p d f$ 
Furman University, Riley Institute. (2015b). South Carolina public Montessori study: 2013-2014 teacher survey (selected summary). Retrieved from https://riley.furman.edu/sites/default/files/docs/MontTeacherSurveySummary13-14_ADS 17.pdf

Furman University, Riley Institute. (2015c). South Carolina public Montessori study: Montessori student demographics. Retrieved from https://riley.furman.edu/sites/default/files/docs/MontStudentData12-13.1.20.15.pdf

Goldsmith, P. R. (2010). Learning apart, living apart: How the racial and ethnic segregation of schools and colleges perpetuates residential segregation. Teachers College Record, 112(6), 1602-1630.

Goyette, K., Farrie, D., \& Freely, J. (2012). This school's gone downhill: Racial change and perceived school quality among whites. Social Problems, 59(2), 155-176. doi: 10.1525/sp.2012.59.2.155

Goyette, K., Iceland, J., \& Weininger, E. (2014). Moving for the kids: Examining the influence of children on White residential segregation. City \& Community, 13(2), 158-178. doi: 10.1111/cico.12058

Helms, A. D. (2015, December 17). CMS Montessori magnets are popular, but some question access. Charlotte Observer. Retrieved from http:/www.charlotteobserver.com/news/local/education/yourschools-blog/article50123080.html

Hochschild, J. L., \& Scovronick, N. B. (2003). The American dream and the public schools. New York, NY: Oxford University Press.

Huck, C. (2015). City Garden Montessori School in St. Louis: A story of education reform, gentrification and housing advocacy. Poverty \& Race, 24(6), 9-11.

Jabbar, H. (2016). Selling schools: Marketing and recruitment strategies in New Orleans. Peabody Journal of Education, 91(1), 4-23.

Johnson, O., Jr. (2014). Still separate, still unequal: The relation of segregation in neighborhoods and schools to education inequality. The Journal of Negro Education, 83(3), 199-215. doi: 10.7709/jnegroeducation.83.3.0199

Kahlenberg, R. (2001). All together now: Creating middle-class schools through public school choice. Washington, DC: Brookings Institution Press.

Kahlenberg, R., \& Potter, H. (2014). A smarter charter: Finding what works for charter schools and public education. New York, NY: Teachers College Press.

Kahn, D. (Ed.) (1990). Implementing Montessori in the public sector. Cleveland Heights, OH: North American Montessori Teachers Association.

Kostin, A. (1995). The Montessori System re-examined: Public Montessori teaching in 1995 (Unpublished master's thesis). Antioch University Seattle, Seattle, WA.

Ladson-Billings, G. (1995). Toward a theory of culturally relevant pedagogy. American Educational Research Journal, 32(3), 465-491.

Laub, P., \& Kim Thomas, H.-S. (2011). Urban Montessori Charter School charter petition. Oakland Unified School District. Retrieved from http://d3n8a8pro7vhmx.cloudfront.net/umcs/pages/16/attachments/original/1374819161/UMCSCharter-to-OUSD-FINAL.pdf?1374819161

Lewis, A. E. (2003). Race in the schoolyard: Negotiating the color line in classrooms and communities. New Brunswick, NJ: Rutgers University Press.

Lewis, A. E., \& Diamond, J. B. (2015). Despite the best intentions: How racial inequality thrives in good schools. New York, NY: Oxford University Press.

Lewis-McCoy, R. L. (2014). Inequality in the promised land. Stanford, CA: Stanford University Press.

Lillard, A., \& Else-Quest, N. (2006). The early years: Evaluating Montessori education. Science, 313(5795), 1893-1894. doi: 10.1126/science. 1132362

Lillard, A. S. (2012). Preschool children's development in classic Montessori, supplemented Montessori, and conventional programs. Journal of School Psychology, 50(3), 379-401. doi: 10.1016/j.jsp.2012.01.001 
McCord, S. (2012, September 9). Santa Cruz City Schools takes public Montessori plan off the table. Santa Cruz Sentinel. Retrieved from http://www.santacruzsentinel.com/general-news/20120919/santacruz-city-schools-takes-public-montessori-plan-off-the-table

McKenzie, G. K. (1994). Instructional leadership practices of Montessori public school principals: The Montessori teachers' perspective (Doctoral dissertation). (Order No. 9506796). Retrieved from ProQuest (304138887).

Meyer, J. W. (1975). Diffusion of an American Montessori education. University of Chicago Geography Research Papers. Chicago: University of Chicago.

Montessori Public School Consortium. (1993). 100 Largest U.S. school systems. MPSC Update, 2(1), 5. Retrieved from ERIC: http://files.eric.ed.gov/fulltext/ED382337.pdf

Murray, A., \& Peyton, V. (2008). Public Montessori elementary schools: A delicate balance. Montessori Life, 20(4), 26-30.

National Center for Montessori in the Public Sector. (2014a). Growth of public Montessori in the United States: 1975-2014. Retrieved from http://www.public-montessori.org/growth-public-montessoriunited-states-1975-2014

National Center for Montessori in the Public Sector. (2014b). 2014 census data snapshot. Retrieved from http://www.public-montessori.org/public-montessori-census-snapshot-2014

National Center for Montessori in the Public Sector. (2016). NCMPS rubric of essential elements of Montessori practice in the public sector. Retrieved from http://www.publicmontessori.org/resources/ncmps-rubric-essential-elements-montessori-practice-public-sector

Nicholson, E. (2016, June 27). With Mata Montessori, did DISD sell its soul for the middle class? Dallas Observer. Retrieved from http://www.dallasobserver.com/news/with-mata-montessori-did-disdsell-its-soul-for-the-middle-class- 8427203

Newton, X. A. (2010). End-of-high-school mathematics attainment: How did students get there? Teachers College Record, 112(4), 1064-1095.

Nyland, L. (2015). Amendment to the new student assignment plan regarding Leschi Elementary blended model for the 2015-16 school year. School Board Briefing/Proposed Action Report. Seattle, WA: Seattle Public Schools.

Orfield, G., \& Frankenberg, E. (2013). Educational delusions?: Why choice can deepen inequality and how to make schools fair. Berkeley: University of California Press.

Orfield, G., Kucsera, J., \& Siegel-Hawley, G. (2012). E pluribus... separation: Deepening double segregation for more students. The Civil Rights Project/Proyecto Derechos Civiles. Retrieved from https://civilrightsproject.ucla.edu/research/k-12-education/integration-and-diversity/mlknational/e-pluribus...separation-deepening-double-segregation-for-morestudents/orfield_epluribus_revised_omplete_2012.pdf

Pattillo, M. (2015). Everyday politics of school choice in the Black community. Du Bois Review, 12(1), 4172. doi: http://dx.doi.org/10.1017/S1742058X15000016

Pattillo, M., Delale-O'Connor, L., \& Butts, F. (2014). High-stakes choosing. In A. Lareau \& K. Goyette (Eds.), Choosing homes, choosing schools (pp. 237-267). New York, NY: Russell Sage Foundation.

Pérez, M. (2011). Two tales of one city: A political economy of the New York City public high school admissions process (Doctoral dissertation). Retrieved from ProQuest (Publication No. 3444338).

Potter, H., Quick, K., \& Davies, E. (2016). A new wave of school integration: Districts and charters pursuing socioeconomic diversity. The Century Foundation. Retrieved from http://apps.tcf.org/anew-wave-of-school-integration

Prothero, A. (2016, March 9). In charters, using weighted lotteries for diversity hits barriers. Education Week. Retrieved from http://www.edweek.org/ew/articles/2016/03/09/in-charters-using-weightedlotteries-for-diversity.html

Reardon, S. F. (2013). The widening income achievement gap. Educational Leadership, 70(8), 10-16. 
Reardon, S. F. (2016). School district socioeconomic status, race, and academic achievement. Stanford Center for Educational Policy Analysis. Retrieved from https://cepa.stanford.edu/sites/default/files/reardon\%20district $\% 20$ ses $\% 20$ and $\% 20$ achievement $\%$ 20discussion\%20draft\%20april2016.pdf

Renzulli, L. A., \& Evans, L. (2005). School choice, charter schools, and white flight. Social Problems, 52(3), 398-418. doi:10.1525/sp.2005.52.3.398

Rhodes, A., \& DeLuca, S. (2014). Residential mobility and school choice among poor families. In A. Lareau \& K. Goyette (Eds.), Choosing homes, choosing schools (pp. 137-166). New York, NY: Russell Sage Foundation.

Roberts, J. C., \& Fleming, D. J. (2016, January). Mapping the landscape of public Montessori in South Carolina. Paper presented at the annual meeting of the Southern Political Science Association, San Juan, Puerto Rico.

Schapiro, D. (2005). Montessori Community Directory. American Montessori Society Records (Box 20160095 1). University of Connecticut Archives and Special Collections, Storrs, CT.

Schapiro, D. (2012). Santa Cruz residents organize to stop public Montessori charter. Public School Montessorian, 24(3), 8.

Smrekar, C., \& Goldring, E. (1999). School choice in urban America: Magnet schools and the pursuit of equity. New York, NY: Teachers College Press.

Stansbury, J. (2014). Dealing with diversity: Administrator, teacher and parent perceptions of the responsiveness of Montessori schools to racial and ethnic diversity (Master's thesis). Retrieved from

https://amshq.org/Publications-and-Research/Research-

Library/ /media/9E1F8E5CC6E2496E8FE8E183D3BE98BE.ashx

Stocking, B. (2015). How a diverse yet divided school blended "segregated" classes. Seattle Times. Retrieved from http://www.seattletimes.com/education-lab/how-a-diverse-yet-divided-schoolblended-segregated-classes/

Swedien, J. (2014, December 3). Montessori charter school supporters fight back. Leader-Telegram. Retrieved from http://www.leadertelegram.com/News/Front-Page/2013/06/04/MontessoriCharter-School-supporters-fight-back.html

Tegeler, P., Hilton, M., \& McArdle, N. (2014, March 13). Community eligibility provision and the future of FRL data. The National Coalition on School Diversity. [Letter to Catherine Lhamon, Assistant Secretary for Civil Rights, U.S. Department of Education]. Retrieved from http://www.schooldiversity.org/pdf/CEP_Letter_for_ED_3-13-14.pdf

U.S. Department of Education, Institute of Education Sciences, National Center for Education Statistics. (2003). Public School Universe Survey, Common Core of Data [Data set]. Available from https://nces.ed.gov/ccd/elsi/tableGenerator.aspx

U.S. Department of Education, Institute of Education Sciences, National Center for Education Statistics. (2007). Public School Universe Survey, Common Core of Data [Data set]. Available from https://nces.ed.gov/ccd/elsi/tableGenerator.aspx

U.S. Department of Education, Institute of Education Sciences, National Center for Education Statistics. (2013). Public School Universe Survey, Common Core of Data [Data set]. Available from https://nces.ed.gov/ccd/elsi/tableGenerator.aspx

U.S. Department of Education, Institute of Education Sciences, National Center for Education Statistics. (2015a). Table 204.10: Number and percentage of public school students eligible for free or reduced-price lunch, by state. Digest of Education Statistics. Retrieved from National Center for Education Statistics https://nces.ed.gov/programs/digest/d15/tables/dt15_204.10.asp 
U.S. Department of Education, Institute of Education Sciences, National Center for Education Statistics. (2015b). Table 216.50: Number and percentage distribution of public elementary and secondary school students, by percentage of minority enrollment in the school and student's racial/ethnic group: Selected years, fall 1995 through fall 2013. Digest of Education Statistics. Retrieved from National Center for Education Statistics http://nces.ed.gov/programs/digest/d15/tables/dt15_216.50.asp

U.S. Department of Education, Institute of Education Sciences, National Center for Education Statistics. (2015c). Table 216.30: Number and percentage distribution of public elementary and secondary students and schools, by traditional or charter school status and selected characteristics: Selected years, 1999-2000 through 2013-14. Digest of Education Statistics. Retrieved from National Center for Education Statistics https://nces.ed.gov/programs/digest/d15/tables/dt15_216.30.asp?current=yes

U.S. Department of Education, Institute of Education Sciences, National Center for Education Statistics. (2016a). Racial/ethnic enrollment in public schools (The Condition of Education 2016). Retrieved from National Center for Education Statistics http://nces.ed.gov/programs/coe/indicator_cge.asp

U.S. Department of Education, Office of Innovation and Improvement. (2016b). Investing in innovation (i3) grants. Retrieved from Office of Innovation and Improvement https://www2.ed.gov/programs/innovation/index.html?exp=0

Van Acker, T. A. (2013). From boutique to big box: A case study concerning teacher change transitioning to a public Montessori elementary school (Doctoral dissertation). Retrieved from ProQuest (Publication No. 3609604).

Wells, A. S., Fox, L., \& Cordova-Cobo, D. (2016). How racially diverse schools and classrooms can benefit all students. New York, NY: The Century Foundation.

Wells, A. S., Holme, J. J., Revilla, A. T., \& Atanda, A. K. (2009). Both sides now: The story of school desegregation's graduates. Berkeley: University of California Press.

Welner, K. G. (2013). The dirty dozen: How charter schools influence student enrollment. Teachers College Record. Retrieved from http://nepc.colorado.edu/files/welner-charter-enrollment-teachers-collegerecord.pdf

Whitworth, M. (2016, January 17). Longview ISD will use savings to build Montessori school. Longview News-Journal. Retrieved from https://www.news-journal.com/news/2016/jan/17/longview-isdwill-use-savings-to-build-montessori-/

Wong, Q. (2014, June 19). State approval of Montessori school in Salem stalls. Statesman Journal. Retrieved from http://www.statesmanjournal.com/story/news/education/2014/06/19/stateapproval-montessori-school-salem-stalls/11004775/

Yezbick, M. (2007). How Montessori educators in the U.S. address culturally responsive teaching (Master's thesis). Retrieved from https://amshq.org/Publications-and-Research/ResearchLibrary/ /media/60D2372C27E34D7D920BA5DCA228B3F4.ashx 


\section{Appendix}

Creating and sustaining racially diverse schools involves strategies for access, outreach, cultural diversity and student support, and advocacy. Below are a number of strategies that have emerged from Montessori research (Ansari \& Winsler, 2014; Debs, 2016a), school diversity best practices (Kahlenberg \& Potter, 2014; Ladson-Billings, 1995; Potter et al., 2016; Welner, 2013), and initiatives created by public Montessori schools (Bologna, Kantor, Liu, \& Taylor 2015; Bowie, 2016; Huck, 2015; Laub \& Kim, 2011) to enroll and support a racially and economically diverse student body.

\section{Access}

- Provide full-day programming and before- and after-school care to support working families.

- Provide transportation to all families.

- Participate in the district lottery process to simplify enrollment for parents.

- Use a weighted lottery to increase enrollment of disadvantaged students.

- Offer sliding-scale tuition if the preschool program is not free.

- Follow federal law mandating that charter elementary schools that have private preschools conduct open lotteries at age 5 to ensure that all students have access to the charter elementary program.

- Offer summer programming.

\section{Outreach}

- Develop a thorough outreach plan and share it publicly with the school community.

- Print brochures in multiple languages, and include translations or a translation service on website.

- Hold information sessions at community libraries, public housing, Head Start facilities, and places of worship.

- Publicize Montessori's efficacy with English language learners and students with special needs.

- Publicize Montessori's rich curriculum related to cultural diversity.

- Share academic results so that parents will know they are choosing a college preparatory curriculum.

\section{Cultural Diversity and Student Support}

- Hire diverse staff, and create school-based pathways for training and hiring from within the local community.

- Use curriculum materials that accurately represent economically and racially diverse students and families.

- Include a parent-outreach coordinator on staff who recruits a diverse population of students and supports a diverse population of families.

\section{Advocacy}

- Advocate for increased public funding for all early childhood students, starting as young as possible.

- Advocate for urban renewal plans that provide for intentional racial and socioeconomic housing diversity, including mixed-income housing and affordable units.

- Advocate for greater support/mandates in federal, state, and local policy to promote racially and socioeconomically diverse schools. 